\title{
Building Bridges To Connect The Disconnects: An Analysis Of Business Program Design Processes
}

Debra L. Fleming, Ursuline College, USA

\begin{abstract}
The purpose of this study is to analyze current trends of design processes and redesign efforts for business programs. A review of the literature suggests business schools are not preparing graduates of their programs with the necessary knowledge, skills and dispositions as deemed appropriate to succeed in the world of work. Some research studies indicate that business schools have lost their relevancy and that there is a significant disconnect between higher education and the corporate world. This study suggests, through examples, that a certain segment of the higher education industry, consisting of the small private independent sector, is on target in preparing their students to succeed not only in the world of work, but also in the world of living. This analysis builds on previous research studies in this area which emphasize the importance of using gap analysis in program design initiatives and extends this work by providing an additional conceptual model for educators to use to ensure that our business programs not only meet the needs of our students, but also exceed employers' expectations. This model emphasizes that to meet the constantly changing workforce needs of employers, business professors must build programs that enable each student to achieve the unique combination of industry, disciplinary and cross-disciplinary performance standards (learning outcomes) appropriate to a given sector of the economy through the integration of best practices in life-long learning and continuous quality improvement. To build the bridges that "connect the disconnects", business professors and employers must work together to create business programs that effectively prepare the workforce for the $21^{\text {st }}$ Century.
\end{abstract}

Keywords: Business Education, Program Design Models, Learning Outcomes, Employer Needs, 21st Century Workforce, Gap Analysis, Benchmarking, Business Courses, Assessment and Accountability

\section{INTRODUCTION}

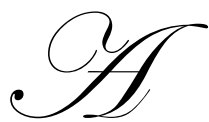

primary purpose of this study is to address common criticisms that have transpired throughout the decades that relate to both the relevance and quality of business programs and to suggest a conceptual framework that can be used to enhance program design efforts. Several national research studies suggest that our educational systems, in general, are not preparing students effectively to succeed in the world of work and the world of living. Some of the critical comments relate to educational programs that have not been revamped to address the constantly changing needs of the workplace, especially when considering the impact of globalization and technology. Changes in the workplace have consequences for the knowledge, skills, dispositions and values that students must learn, for the ways in which they are taught and for the assessment standards to which they are held accountable. These types of changes directly effect how we should think about the "connections" between education and earning a living.

\section{CALL TO ACTION FOR EDUCATIONAL PROGRAMS}

A review of the literature suggests that criticisms related to business programs, such as the lack of relevance in program content that is required to meet employer expectations and the inability to prepare students to 
succeed in the world of work, is not an isolated debate. Throughout the decades there has been a national debate on whether or not our educational programs are preparing students to succeed in the work environment.

On April 26, 1983, the United States Department of Education's National Commission on Excellence in Education published a report, A Nation at Risk. This document is often cited as the origin of current educational reform efforts because it contained disheartening findings on the state of education. The report stated "our Nation is at risk because the educational foundations of our society are presently being eroded by a rising tide of mediocrity that threatens our very future as a Nation and a people." Interestingly, approximately eight years later, this message was repeated on April 18, 1991, when the President of the United States announced a new education strategy, "America 2000," he said, "think about every problem, every challenge, we face. The solution to each starts with education. For the sake of the future of our children and the nation, we must transform America's schools. The days of the status quo are over." As part of this educational strategy, President Bush also signed into law the No Child Left Behind Act (NCLB) on January 8, 2002. The act contained the basic education reform principles of stronger accountability for results and an emphasis on teaching methods that have been proven to work. Since then, educators have participated in federal and state initiatives to support higher student achievement and a better-prepared teacher workforce.

Interestingly, in 1991, as part of the U.S. Labor Department's role to help educators address program revision related to workforce changes, the Secretary's Commission on Achieving Necessary Skills (SCANS) issued the report What Work Requires of Schools, and its companion report, A Blueprint for Action: Building Community Coalitions. These reports were instrumental in both identifying and defining a common core of skills, competencies and outcomes that individuals must obtain to be successful in the jobs of today and tomorrow. Their extensive research efforts focused on asking employers what their workforce requirements were and asking educational institutions if these requirements were incorporated effectively into the curriculum. The SCANS work was validated, when The National Council on Education Standards and Testing endorsed the workplace competencies defined by SCANS when the Council recommended that the skills be integrated into national standards and assessments of core academic subjects. The final SCANS report, Learning a Living: a Blueprint for High Performance, provided several recommendations on how to prepare workers for the high performance jobs of the future. The purpose of this report was to provide a detailed framework or roadmap for how educators and businesses could work together to improve the nations' productivity and the well-being of its citizens for work in the $21^{\text {st }}$ century.

In addition, the $21^{\text {st }}$ Century Workforce Commission states that "the current and future health of America's $21^{\text {st }}$ century economy depends directly on how broadly and deeply Americans reach a new level of literacy called " $21^{\text {st }}$ Century Literacy" which includes strong academic skills, thinking, reasoning, teamwork skills, and proficiency in using technology". This report repeats the message that every worker needs to acquire higher levels of education and training, commonly referred to as "employability skills" to succeed in today's and tomorrow's economy. A set of similar skills, referred to as a "twenty-first century liberal education", was included in the American Association of Colleges and Universities (AACU) report on Greater Expectations. This was a major initiative of AACU from 2000-2006.

Unfortunately, this educational debate is still occurring today and there is minimal research on whether or not anything improved significantly within the educational sector. Since the publication of A Nation at Risk more than 20 years ago, governmental agencies have been engaged in various efforts to improve the quality of educational programs, especially within the elementary and secondary schools. One example of higher education's responsibility in this effort has been centered on preparing future teachers who are masters of their subject areas. However, knowledge of how well the nation's colleges and universities are fulfilling this responsibility remains limited. For example, in a report on the state of U.S. education over the past few decades, The Koret Task Force, commissioned by the Hoover Institute of Stanford University in California, concluded that "The tide of mediocrity remains high." In addition, they point out, while SAT scores have improved since 1982, they are still below their 1970 levels. At the same time, scores on the National Assessment of Educational Progress have remained fairly flat over the years. The chairperson of the Koret Task Force, Chester Finn, stated that "since 1983 there has been a lot of effort, goodwill, activity and money spent on our school systems, and yet very little to show for it by way of 
improvement." Even though Finn agreed that the publication of A Nation at Risk was a major event for educational reform, he concluded that "the report made a lasting contribution by changing national conversations about education: it set the stage and brought the audience into the room and even played the overture, but what it didn't do was to deliver the opera" (Chubb, 2004).

This sentiment is echoed in Measuring Up 2006, a national report card published by the National Center for Public Policy and Higher Education which addressed how the states and nation educate and train the future workforce. In Measuring Up 2000, the first state-by-state report card on higher education performance, all 50 states received an "incomplete grade" in the category of learning. Six years later, the 2006 report also concluded that the states received an incomplete grade in the area of learning. This report card examined high school preparation through the bachelor's degree, and the contributions of public and private, two- and four-year, non-profit and forprofit colleges and universities. Their reports suggested that while progress has been minimal since the 1990s, much of the rest of the world has improved in the area of educating more people to higher levels and that the U.S. is underperforming in higher education.

James B. Hunt Jr., former Governor of North Carolina and Chairman of The National Center for Public Policy and Higher Education, suggested in the Measuring Up 2006 report, that to address these problems a sense of urgency was needed among policy leaders, educators, and business leaders comparable to the policy emphasis that other countries have placed on higher education. Thus, the states need to more effectively educate students with college-level knowledge and skills that are deemed relevant to succeed in the workplace of the future. Overall, the results of these reports indicate that assessment and evaluation of student learning are critical factors in determining whether or not educational programs are effective in preparing students with the skill sets deemed appropriate to succeed in the world of work and the world of living.

In summary, one of the most important outcomes of these reports is that they have been instrumental in identifying the combination of foundation skills and workplace competencies that should be integrated into all educational program endeavors. As outlined in the SCANS reports, "a high performance workplace requires workers who have a solid foundation in the basic literacy and computational skills, in the thinking skills necessary to put knowledge to work, and in the personal qualities that make workers dedicated and trustworthy". In addition to the foundational requirements, high-performance workplaces also require competencies: "the ability to manage resources, to work amicably and productively with others, to acquire and use information, to master complex systems, and to work with a variety of technologies". This combination of foundation skills and workplace competencies is commonly referred to as workplace know-how and/or employability skills. All of these reports are critical elements of a broad nationwide effort to build bridges that link education to the real world. All seek a particular kind of learner, one who can put knowledge and skills into practice as a productive worker and socially responsible global citizen.

Even though the focus of the previously sited research was directed at educational systems in general, a related sector of education that focuses on preparing students for the world of work - is business programs. Interestingly, some of the same criticisms apply to this sector as well. Business schools have been facing an increasing amount of criticism on a national basis. The most common theme across the criticisms that focus on business education is that schools face the challenge of continuing to make business programs current, relevant, and timely. Therefore, business programs are viewed by some as disconnected from the real world.

\section{CALL TO ACTION FOR BUSINESS PROGRAMS}

An important subset of our higher education sector that focuses directly on preparing future business leaders with the necessary competencies to succeed in the world of work consists of undergraduate and graduate business programs. These programs have existed for decades and have been recognized as credentials for career enhancement or professional development within the corporate world. Recent scandals such as Enron or WorldCom have heightened the debate on whether or not business schools are preparing graduates of their programs with the necessary knowledge, skills, dispositions and values necessary to lead businesses forward within an increasingly competitive, technology enhanced, global environment that is constantly changing. Some research studies indicate 
that employers are questioning the value of traditional business programs and some perceive business degrees in the higher education sector as disconnected from the working environment (Barker, Gilbreath, and Stone, 1998; Bain, 1992; Elliott and Goodwin, 1994; Hirsh, Burgoyne and Williams, 2002; Pferrer and Fong, 2002). One business program critic, Henry Mintzberg, a professor at McGill University, suggests that business schools are no longer relevant and that the primary reason is a less-than-relevant curriculum. In his book, Managers Not MBA's, Mintzberg questions whether business schools can graduate well prepared $21^{\text {st }}$ century business leaders based on programs first introduced in 1908 and not revised since the late 1950's (Mintzberg, 2004). Other critics of business school programs most commonly cite shortcomings such as, business schools do little to produce future leaders who have the capabilities to meet the challenges of the changing global business environment and faculty lack appropriate business experience or they spend too much time on producing esoteric research for academic scholarly journals which may result in faculty not effectively teaching students what is applicable to the work environment (McKenna, Cotton, and Van Auken, 1995; McNamara, 2006).

In 2002, the American Association of Collegiate Schools of Business (AACSB), Management Education Task Force, published the report, Management Education at Risk. Similar to the call to action for all educators in a Nation at Risk, the AACSB report was a call to action for business educators to address the changing context in which business schools operate and to consider new strategies and alliances that have been rare among business schools. This report was built upon two other AACSB reports produced in 1988 and 1996: Management Education and Development: Drift or Thrust into the 21st Century and A Report of the Faculty Leadership Task Force. The 2002 AACSB report, similar to the SCANS report in 1990, maintained that two broad problems confront business education: the need to focus on basic foundational skills such as communication, interpersonal skills, and leadership; and the need to enhance relevancy by designing outward facing curricula. This report also suggested that business schools need to connect scholarship with current business issues and that business programs must pursue current content and use effective pedagogies, including action learning and technology to enhance learning. It is important to note that other studies indicate that relevance and reality are often considered to be absent from business programs and that many educators have risen to the challenge by providing action-based learning and live cases in an attempt to integrate realism back into learning (Elam and Spotts 2004; Razzouk, Seitz and Rizkallah 2003; Tabor 2005; Young 2002; Zych 1997).

Equally as important, the AACSB report emphasized the prospect of greater reliance on employing business faculty who not only have the required educational credentials, but also have practical real-world business experience in an effort to enhance realism. The AACSB report suggested that future program design efforts should integrate both theory and application and that business programs should include a more integrated, entrepreneurial approach to program design which involves breaking down the boundaries among traditional, functionally-based disciplinary silos. Interestingly, almost twenty years ago in 1988, previous research also provided similar recommendations that business schools should provide an integrated education, rather than an assortment of individual discipline related courses (DeConnick and Steiner, 1999; Porter and McKibbin, 1988). Others suggest that integration across business functions is a critical area where business programs need improvement and that business programs must blend knowledge, integration, and application together (Hancock, 1998). Most business programs consist of courses associated with functional areas that are taught in isolation from each other, such as accounting, finance, marketing, information systems, operations, and management. Changing economic forces and research show the need to abandon these vertical, functional organizational structures, which are characteristic of traditional program design initiatives, in favor of a more horizontal, cross-functional structure that is incorporated into program offerings (Closs \& Stank, 1999). Just as organizations are seeking to reengineer their business processes, in part, to move away from functional disintegration, business education has also begun to question its functional orientation approach for program design and/or redesign efforts (Becerra-Fernandez, Murphy, \& Simon, 2000).

Additional research indicates that many business programs seem bound by the traditional program design approach that focuses on the core functional areas of business which often results in the unmet needs of corporations that operate within a constantly changing, highly competitive global business environment (Carruth and Carruth, 2006). Critics of the traditional program approach argue that students primarily learn how to crunch numbers, and that business programs in general fail to adequately address important skills and values, such as teamwork and ethics 
(Stern, 2004; George, 1987; and Katz, 1990). These skills are commonly referred to as the "soft" skills, whereas the hard skills set usually includes, accounting, finance and statistical knowledge. According to other research studies the soft skills set are the skills that can result in success or failure for executives in the real world. These studies suggest that business schools have struggled in their efforts to implement these areas in the core curriculum. A related study of the top 50 U.S. business schools revealed less than a third require non-traditional, non-number crunching courses like human resource management, negotiations, leadership, and entrepreneurship (Navarro, 2004). Yet, today in U.S. businesses there is a great demand for executives who can manage entrepreneurial creativity among employees. Outsourcing, fast changing technology, and evolving customer expectations require that companies quickly adapt the way they operate (Elliott and Goodwin, 1994; Dertouzos, Lester and Solow, 1999). Presidents of large corporations must have managers that can supervise innovation and direct strategic crossfunctional design teams (Aurand, DeMoranville, and Gordon, 2001; Business Week, 2005; George and Davis, 2000). The global business world is one of ever changing demands and expectations, thus for business programs to maintain their relevance, they must be innovative and adaptive (Conger and Xin, 2000; Dertouzos, Lester and Solow, 1999). They must provide their graduates with not only traditional managerial skills, but also ethical and socially responsible skills (Barker, Gilbreath, and Stone, 1995; Behrman and Levin, 1984; Etzioni,2002; Alford and Naughton, 2001; George, 1987; and Katz, 1990). As previously noted, these same skill sets were also included, decades ago, in the 1991 SCANS report.

Other studies stress that business faculty must assess not only their teaching methods, but also the content of their research, and that they must develop measures of quality in terms that benefit not the school nor the faculty members, but rather the businesses that hire their graduates. (Davis, 1993; Glaser, 1990; McKenna, Cotton, Van and Auken , 1995; Davis, 1993; McNamara, 2006). A recent Harvard Business Review article entitled How Business Schools Lost their Way, stressed that business schools are hiring professors with limited real-world experience and graduating students who are not equipped to handle complex, unquantifiable issues. This article raised questions about "whether business schools in general have lost their relevance by following the scientific model of arts and science schools as opposed to the professional model of medical and law schools. The professional model combines practice and theory and assumes that most or all faculty will have some practical experience" (Bennis and O'Toole, 2005). Other articles suggest that the lack of relevancy in some business programs is related to an emphasis on research rather than teaching (McKenna, Cotton, and Van Auken, 1995). These articles conclude that this type of research emphasis "has led to a significant and increasing disconnection between the world of management practice, for which most business school students are being prepared, and the world of higher education in which faculty members who teach and research management issues are being prepared, hired, and promoted" (Heskett, 2005; Conger and Xin, 2000; Glaser, 1990; Phelps and Kimball, 1994; and Phelps, Aggarwal, and Taylor, 2006).

Some business school deans also point out that business programs are not relevant in meeting employer expectations. For example, Dr. Christoper P. Puto, Dean of the University of St. Thomas's business programs, in a column in the May 22, 2005 Minneapolis Star-Tribune emphasized that business schools have been missing the mark in the way they educate tomorrow's business leaders, especially in regard to not incorporating ethics and social responsibility more directly into their courses. Equally as important, he also emphasized that it is inappropriate to lump all business schools under one heading. He states that when analyzing such criticisms, it is important to distinguish between the established business schools and the smaller emerging schools because when it comes to innovation, the differences often are significant. For example, Puto stressed that "trapped by the inertia of their past successes and the unwieldy nature of traditional curriculum design, the established business schools -- Harvard, Columbia, Wharton and UCLA -- are restricted in their ability and freedom to innovate". He concluded that "they have too much to lose and too many built-in institutional impediments to achieve rapid change and that in today's environment, the smaller, emerging business schools are freer to operate at the leading edge of program innovation and curriculum development" (Puto, 2005).

This sentiment was echoed by Dr. Debra L. Fleming, a previous Business School Dean at Dowling College in New York, during a Long Island Business Association's meeting in 2004. Fleming stressed that many of the criticisms about business program design efforts do not relate to the smaller, private independent sector of higher education, especially for those schools that have strong religious affiliations. She noted that in comparison to the elite research universities, the business schools within the private sector of higher education have different missions, 
different faculty promotion structures and different curricular reform policies. Most importantly, the mission of these schools are to build interconnected programs based on a strong liberal arts foundation which includes a holistic, values-based approach to learning to ensure that each student is prepared with the necessary skill sets to become ethical and socially responsible leaders in a global community. This means that graduates of their business programs are equipped with both the soft skills set and the hard skills set that have been identified in the SCANS skills documents and other reports as necessary for preparing the $21^{\text {st }}$ century workforce. In addition, she emphasized that a major educational benefit provided by these schools is that their business professors, not only have excellent academic credentials in their field, but also have practical real world experience which interjects realism into the class room setting. Another major attribute of schools in this sector is that their faculty promotion and reward structures focus on effective teaching and innovative curriculum development as a top priority, rather than focusing on the production of esoteric research as the most important priority. She concluded that these factors contribute to their professors' effectiveness in business program design efforts that create relevant, timely and current programs that build the bridges for connecting higher education with work place learning (Fleming, 2004).

In summary, for schools of business, the general message being communicated to them is that companies are unhappy with the outdated training and education that is provided by some of the schools in the higher education sector. As a result, an increasing number of businesses are choosing to train their employees in-house, not just because of cost savings, but also because of the failure of business schools to teach the knowledge and principles they deem essential in today's competitive world (Business Week, 2005). For example, IBM spends more than $\$ 2$ billion annually on training and education which includes both degree and non degree expenditures. Corporate University Xchange estimates that the number of corporate universities totals 2000 which is up from only 400 about 15 years ago and they predict that the number will grow to 3,700 by 2010 (AACSB, 2002). Thus, rather than creating an environment where educational institutions are not preparing students effectively and corporations are starting to do it themselves, business educators must focus on how to create effective partnerships among education and businesses to design and/or redesign business programs to effectively meet the needs of their constituencies.

Clearly, the challenges facing business education are many and varied; but because the educational market is so fragmented among private, public and profit-oriented organizations, it is difficult to develop a single set of solutions (Bain, 1992; Behrman and Levin, 1984). Therefore, a fundamental purpose of this exploratory study is to not only examine some of the basic criticisms that relate to the lack of relevance of business programs, but also to suggest recommendations for enhancing its relevance in today's constantly changing, complex business environment.

Generally speaking, most would concur, that the focus of higher education's business programs should be on critical and adaptive problem solving, and not just information dissemination disconnected from the workplace. For business schools to remain viable, they must be readily able to adapt to changing demands and expectations of their constituents. Just like businesses, educational institutions need the ability to reinvent their programs using an integrated design approach related to the shifting global business environment (Conger and Xin, 2000; Malekzadeh, 1998; Goodswell, Maher and Tinto, 1992; Dinmore, 1997; Slater, Smith, McCubbery and Scudder, 1995; Whetten and Clark, 1996).

As previously noted, numerous work place skills and abilities are needed in today and tomorrow's future work environment to create and sustain competitive advantages due to advancements in technology and the impact of globalization. Therefore, if schools of business are going to be the primary provider of business education in the future, they must be up to the challenge of providing students with more than just specialized knowledge of the basic functional areas of business (Aurand, DeMoranville and Gorden, 2001). They must provide their students with the skills to act upon such knowledge, thus not just "knowing", but also "doing". Equally as important, they must instill in their students essential leadership attributes such as veracity, sound judgment, insight, and the ability to think innovatively" (Carruth and Carruth, 2006). From a practical perspective, it is important to note that the end result is to produce graduates with the knowledge, skills, dispositions and values that employers consider important (Barker, Gilbreath, and Stone, 1998; Carruth and Carruth, 2006; Conger and Xin, 2000). 
As indicated in the plethora of research that focuses on criticisms of educational programs, employers want business graduates who can provide creative solutions that cut across business functions. They want individuals who have been taught how to think ethically about business problems not as a series of unconnected functional business silos but as in integrated cross-functional whole. Therefore, the business world needs business programs that treat business as an integrated whole, teaches students how to work in teams, is applicable to real life problems, ensures that individuals learn necessary foundation skills, but loses none of the rigor of traditional programs (Aurand, DeMoranville, and Gordon, 2001; Whetten and Clark, 1996; Dinmore, 1997) . A key development in educational programs for the $21^{\text {st }}$ century is the concept of integrating education with work place learning to build the bridges that connect the disconnects. Unfortunately, some educational institutions and some faculty are typically slow to adapt. Some business faculty may be a major obstacle to an integrated program, as they may perceive it is easier to teach traditional stand-alone courses where they have more individualized control. In addition, because of minimal performance rewards or incentives at various institutions, some faculty may not be motivated to adapt to new processes. As some would say, in certain cases of the higher education sector, getting faculty to change may be like "trying to move a cemetery". Nevertheless, business faculty must not operate independently where they often duplicate teaching, research, and service efforts and do not integrate the total teaching experience to their students. It is clear from the research that integrated programs are the future of business education and lifelong learning for both graduate and undergraduate business students. (Slater, Smith, McCubbery and Scudder, 1995; McKenna, Cotton, and Van Auken, 1995). Thus, a fundamental question to address is: if we build on previous research that identifies the basic skills, competencies and outcomes which are referred to as "work place know how and employability skills" and we create flexible delivery structures to accommodate changing students' needs, then what type of processes or models can be used by business educators to ensure that business programs are relevant in meeting employers' expectations?

\section{OVERVIEW OF CONCEPTUAL FRAMEWORK PROCESS}

As noted in previous sections of this study, the challenges for business education in the current decade are fundamentally the same as they were in previous decades which could be viewed as holding on to what is of value while discovering what creates added value for activities that are in alignment with customer needs (Bain, 1992; Hirsh, Burgoyne and Williams, 2002). When thinking through how best to design and/or redesign business programs that are relevant in addressing the changing needs of our students while simultaneously meeting employers' expectations, it is important to build on previous research efforts, rather than spending hours trying to 'reinvent the wheel'. Not only were the SCANS and the AACSB reports instrumental in identifying workplace know how or employability skills and competencies, these reports also referenced the importance of how to work collaboratively with businesses within the local community to enhance program development initiatives. Other studies that focus on business program design processes emphasis the importance of using benchmarking or gap analysis techniques to enhance the effectiveness of carving out distinctive market niches and/or using best practices in teaching and learning to enhance the relevance of curriculum development processes.

Within the higher educational sector, business design efforts and curriculum development initiatives are generally the sole responsibility of the faculty who teach in a specific discipline. Interestingly, when business faculty are hired they typically inherit preexisting business programs which may consist of a variety of majors, concentrations or learning tracks within business related fields such as accounting, finance, marketing, management, human resources, or information systems. Faculty members are usually hired based on their academic credentials and expertise in a narrow domain, rather than based on their demonstrated ability to design or redesign effective programs. In addition, business faculty who complete bachelors, masters and/or doctorate degrees in a business related field are not exposed to formal training on instructional design. These issues contribute to random and/or periodic program development revisions, rather than significant, systematic revisions to programs. On the other hand, there may be times when a faculty member decides that a new program or major area of study should be developed because faculty have specific expertise in an area in which the institution does not currently offer. Or the administration may ask faculty members to develop a new program because they think there is a market need for such an endeavor. However, the most common situation that most business faculty members encounter is that of maintaining existing programs (i.e., the status quo) rather than that of significantly revising or building new programs that are directly connected to the marketplace. Nevertheless, an important issue that is raised in regard to 
new program development or program redesign efforts is: what models, processes or frameworks should one use to ensure that the business related program initiatives are relevant in meeting the changing needs of students while simultaneously meeting employer expectations? This study recommends a conceptual framework process that suggests the most effective process for program design efforts includes a combination of building collaborative partnerships with businesses, employing benchmarking techniques and applying gap analysis using a conceptual model that builds on previous research.

Some business educators use benchmarking techniques or gap analysis in their program design efforts. Benchmarking, first introduced by Xerox in the mid 1970's, has seen growing usage throughout schools of business (Stephens and Ohara, 2001; Amin, 2003). One of the most important features of the benchmarking process is to assess what others are doing. More specifically, this process involves an analysis of best practices in regard to what other schools are doing in the area of program development initiatives. This study suggests that this process should not only include an examination of schools that are similar in regard to mission and vision, but also should include an investigation of those business programs at schools that have different missions, such as an aspirant group (e.g., those to which you would aspire to be) and a local competitor group (e.g., schools within local proximity, such as a 45 to 60 mile driving radius). This process includes identification of best practices. This characterization can be made through contacting accrediting bodies, like the Association to Advance Collegiate Schools of Business (AACSB) which is considered to the be the premier accreditation agency in business, or through an extensive literature review (Aupperle, 2003). It is important to note that "among other things benchmarking brings out new methods, ideas and systems to improve curriculum effectiveness" (Hall and Young, 2007).

Some studies define benchmarking as a process that provides feedback for supporting continuous improvement through a combination of internal review and external assessment (Stephens, 2001; Hall and Young, 2007). They suggest that the basic steps common to most benchmarking processes as related to curriculum development include the following: "1) Identify key variables; 2) Identify the best practices for schools having a similar mission; 3) Characterize the performance of each school; 4) Measure the performance of your school; 5) Develop an action plan; and 6) Implement the plan" (Hall and Young, 2007). These studies also indicate that benchmarking enables curriculum designers to develop more viable designs using a systematic approach that takes into account the various constituencies such as, students, alumni, and the business community (Hall and Young, 2007).

In contrast to other studies, this study suggests that benchmarking is more than just a comparative analysis. For example, the first step in the benchmarking process would be to decide what "it" is you want to accomplish, referred to as "IT". The next step would be to research best practices on what others have learned about IT, regardless of their mission statements, followed by defining IT precisely based upon the review which defines best practices benchmarks. The follow-up step would be to find institutions, regardless of type, that does IT outstandingly to determine institutional benchmarks and then incorporate gap analysis into the process.

In addition to using benchmarking techniques for program redesign efforts, some business faculty use gap analysis processes that are in alignment with changing employment opportunities to determine new program development opportunities or to identify program revision initiatives. Some research studies suggest that gap analysis or segment targeting "systematizes the development of a portfolio of skills that are important for business students" (Phelps, Aggarwal and Taylor, 2006). They also conclude that "gap analysis provides a mechanism for monitoring that portfolio currency to be sure the curriculum is always oriented to provide students with skill sets aimed at jobs with the greatest potential for professional growth." Their research also provided formalization of a focused process that targets areas of employment with the most potential for growth in the future (Phelps, Aggarwal and Taylor, 2006). Additional studies, indicate that business schools are finding it necessary to more clearly focus their programs in order to succeed in a more competitive environment and that some schools have increased their applications through adoption of more focused programs (Gerdes, 2005). 


\section{OVERVIEW OF CONCEPTUAL FRAMEWORK}

This study builds upon previous research in the area of using both benchmarking and gap analysis for designing and/or revising business related programs. In addition, this research recommends a conceptual framework process that includes direct collaboration with corporate executives as a critical success factor for the design or revision stages to enhance the process of building the bridges that connect higher education with the corporate world. The stages of this conceptual framework are built upon Bloom's taxonomy of learning domains. This taxonomy of learning behaviors can be thought of as the goals of an educational process. That is, after the educational sessions are completed, the learner should have acquired new skills, knowledge, and/or attitudes that contribute to future program enhancement initiatives. This taxonomy is organized in a hierarchal way to organize information from basic factual recall to higher order thinking. Bloom's research was instrumental in identifying several learning domains; however, the conceptual model in this study focuses only on the cognitive domain which involves knowledge and the development of intellectual skills. This includes the recall or recognition of specific facts, procedural patterns, and concepts that serve in the development of intellectual abilities and skills. Bloom identified six major categories of the knowledge domain, which are listed in order below, starting from the simplest behavior to the most complex. The categories can be thought of as levels of accomplishment or degrees of effectiveness. That is, the first one must be addressed before the next one can take place (Bloom, 1956).

To maximize the results obtained from effective implementation of the conceptual framework process, the various steps in the process were combined into stages that are in alignment with Bloom's six levels of the taxonomy as follows. The first part of the explanation for each level consists of Bloom's definition, followed by a brief explanation on how the level applies to the various stages of the conceptual framework process.

Level 1: Stage One > Knowledge: Bloom defined the knowledge level as gathering factual information and/or identifying terms, principles, and definitions. The conceptual framework approach suggests that stage one of the process should focus on gathering detailed information about the student body. This includes classifying and categorizing students' characteristics according to their specific program area of study.

Level 2: Stage Two > Comprehension: Bloom defined the comprehension level as translating ideas from one context to another, and/or interpreting and extrapolating to grasp meaning of informational materials. The conceptual framework approach suggests that stage two of the process should focus on summarizing both future employment projections and employers' expected skills sets.

Level 3: Stage Three > Application: Bloom defined the application level as using rules and principles in certain situations and/or using information in new and concrete situations to solve problems. This study suggests that stage three of the conceptual framework consists of determining best practices associated with program design efforts. This step includes not only reviewing best practices of schools that are similar in mission and vision, but also reviewing schools that are classified into an aspirant group and a competitor group which may have different missions and/or visions.

Level 4: Stage Four > Analysis: Bloom defined the analysis level as breaking down and making clear the nature of components and the relationship between them and/or breaking down informational materials into component parts to develop conclusions. This study suggests that this stage of the conceptual framework consists of using gap analysis to compare and contrast other programs with existing programs in order to identify holes or gaps in which new courses or programs need be to be revised or developed.

Level 5: Stage Five > Synthesis: Bloom defined the synthesis level as arranging and assembling the elements to develop a new statement, plan or conclusion and/or creative application of knowledge to produce a new or original whole of conclusions. This stage in the conceptual framework consists of creating and/or designing new learning paths, new courses, and/or new learning activities and assignments that are relevant and connected to the world of work. 
Level 6: Stage Six > Evaluation: Bloom defined the evaluation level as assessing the value of methods or approaches regarding internal accuracy and consistency and/or judging the value of materials developed. This final stage of the conceptual framework includes developing formal assessment processes to justify, reframe or revise the program plan which includes systematic feedback processes to support continual improvement.

\section{THE CROSS-FUNCTIONAL DESIGN TEAM}

Not only is it important to identify the various stages in the conceptual framework, but also it is equally as important to identify the members of the program design team who are responsible for developing program design initiatives. A critical success factor for effective implementation of the framework is to build a collaborative, crossfunctional design team. This team would consist of faculty members and corporate executives. This study suggests that business faculty develop a hands-on "working advisory board" of corporate leaders or that they form a "working relationship" with various corporate executives who become part of the design team. As previously noted, various research studies, such as the SCANS and AACSB reports, indicated that one way in which program design efforts could be enhanced is to create collaborative partnerships with local employers to seek information not only on the specific outcomes and skill sets that they deem as appropriate for their current and prospective employees, but also to assist in the design of course assignments or activities that are deemed relevant and connected to real world issues. This means that faculty members are considered content experts in their respective disciplines and the corporate executives become the industry/workplace design experts.

A primary reason for combining these two sets of experts is to enhance the relevancy of course content and to ensure that the learning activities and assignments combine both theory and the application of that theory to real world problems. Another reason for building the collaborative design team is to eliminate or diminish corporations working in isolation from educational institutions when developing corporate universities to educate or retrain their employees to meet their specific needs. Another benefit of building these relationships would be to recruit corporate executives as future adjunct instructors who have real world experience and/or to recruit some of them to serve as guest lecturers and/or speakers for particular courses. It is important to note that this part of the conceptual framework process results in maximizing business faculty efforts in "building the bridge to connect the disconnects" that exist between higher education and work place learning.

Furthermore, to ensure the effectiveness and efficiency of the design team efforts it is important to create a mission, vision and focal point for the design team initiatives. In this research study the design team's mission was to meet the workforce needs of local employers and their employees by building an integrated business related program that would enable each employee/student to achieve unique combination of industry, disciplinary and cross-disciplinary performance standards (learning outcomes) appropriate to a given sector of the economy through the integration of best practices in adult, life-long learning and continuous quality improvement. The design team would serve the local employers and their employees (and views them not as consumers of pre-existing programs which the team markets to them, but, rather, as co-designers of programs that meet their needs in the context of the College's and the team's mission). Thus, the team would apply the rigor of academic disciplinary thinking to the solution of important workforce development needs.

In contrast to other such programs, the design team works with business leaders in various sectors of the local economy to develop solutions to their challenges - as they define them - and actively engages them with the team in the design of their solutions. It accomplishes this by starting from the definition of a workforce challenge from an employer's point of view or from the point of view of representatives of an employment sector. Working with them and a team of faculty content experts, it then identifies the relevant industry, disciplinary, and crossdisciplinary standards of performance employees/students must achieve to succeed and designs programs based on the information gathered in other stages of this framework to enable each employee/student to do so using best practices in adult, life-learning learning.

Employers work with the team to design real world assignments that not only develop students' knowledge, skills, dispositions and values, but also develop the skills that are necessary to succeed in a specific job-related 
domain in the context of the relevant discipline or set of integrated disciplines. Assignments are also specifically designed to ensure that students develop knowledge, skills, dispositions and values that are necessary for their (and their employers') success throughout today's constantly changing, increasingly competitive, knowledge-based, global economy. These skills include the ability to work well in and lead teams; effective oral and written communication skills; quantitative reasoning and critical thinking skills; the disposition toward ethical civic responsibility and respect for diversity; the ability to find information relevant to a challenge, evaluate and synthesize it, and apply it appropriately within the context of the challenge, as well as others that were identified in previous sections of this study.

Equally as important as creating a mission and vision for the design team is to define the core competencies of the members. To serve its markets in the context of its mission and vision, the team should consist of a group of individuals with the following core competencies:

1) developing strategic partnerships and alliances with customers, other academic institutions, and potential providers of the expertise, knowledge, tools or resources needed to address the challenges of the local workforce;

2) assessment and forecasting of local, continuously changing, workforce needs;

3) design and implementation of (e.g., Six Sigma) continuous quality improvement processes to ensure the continuous improvement of its programs in parallel with continuous change of workforce needs;

4) continuous environmental scanning and synthesis of what is emerging from major research centers on adult learning and cognition and of the practical application of this knowledge the best practices in adult educational programs;

5) implementing the small, independent, private College's personal college vision of enabling each student (rather than most students) to achieve high levels of performance through best practices in enhancing learning with technological resources;

6) continual recruiting, building and managing teams of relevant design experts from industry and academia;

7) identification of existing learning resources (wherever they may be) which may be adapted to the task at hand to minimize program development costs and to create an efficient means of designing solutions where no existing resources are available; and

8) monitoring each individual student's learning within and across courses over time which enables customization of learning environments to meet each student's needs.

\section{IMPLEMENTATION OF THE CONCEPTUAL FRAMEWORK}

The following sections provide concrete examples on how to implement the conceptual framework for program redesign processes to ensure that business related programs are relevant in meeting employer's expectations while simultaneously preparing students with the employability skill sets to succeed in the world of work and the world of living. This research effort focused on an analysis of an undergraduate accounting major that had originally been created in the seventies at a small, private, independent College in Ohio. A primary goal of the research conducted was to build an effective program that starts where the students are in terms of knowledge, skill, and abilities and empower them to achieve high standards of excellence. A secondary goal was to identify and organize educational learning processes associated with the integration of accounting, business, and information systems to create an integrated and enhanced, cross-functional business related program, as opposed to continually revising a functionally-based traditional accounting program. The third goal of the research was to devise an educational learning framework that accomplishes maximization of student performance and that adds value to students' lives by providing them with the knowledge, skills, and abilities to become productive and effective members of society in the 21 st century.

A primary objective of the redesign effort was to build a rigorous outcomes-based curriculum that utilized appropriate, effective pedagogical methods to generate an interdisciplinary, connected, cumulative, collaborative, and discovery-based learning environment that provided students with the capacity to 'transfer' and to 'apply' their educational experience to real-world situations. Other objectives were to maximize the effectiveness of these pedagogical strategies through the appropriate use of technology as a digital tool for learning and to create a 
program in which students achieve high levels of performance in the integration and use of the theory, methods, and tools in the disciplines of accounting, business, and information systems. To work toward achieving these goals and objectives, the design team would have to establish a paradigm shift in the way students work and the way faculty teach by employing pedagogical methods that move away from the traditional rule-based, procedure-oriented lecturing, passive learning environment to a dynamic, interactive, and collaborative learning environment. In this new paradigm, the student is viewed as an active learner who uses information to construct knowledge, exercises judgments, evaluates alternative courses of action, and solves real-world open-ended problems.

After defining the primary goals and objectives, the next step in the research process was to apply the six stages of the conceptual framework process associated with program redesign efforts. These stages included gathering factual knowledge of the student body, identifying employers' expectations, comprehending employment projections, reviewing best practices information, analyzing program gaps, synthesizing program elements, and evaluating program components.

\section{STAGE ONE: KNOWLEDGE OF STUDENT BODY}

The first stage in the conceptual framework process is to gather factual background information about the students' enrolled at the College, such as education, experience, and demographics. This study suggests that an electronic or digital portfolio for each student should be developed which consists of information related to students' characteristics upon entry into a program and information about students as they progress through a designated program of study. This information would be used to track the individual learning path of each student from the time he or she enters College until the time a degree is completed. If faculty members have this information in advance of students enrolling in their courses, then they have the opportunity to structure learning activities appropriate to the needs of their students to ensure that they have addressed the diversity of their students' learning styles so that each student has an opportunity to succeed. Unfortunately, what typically happens in practice is that faculty members do not have detailed information about their students' abilities or skill sets until they have graded various assignments within a course as it progresses along the continuum throughout a semester or quarter basis which may diminish the effectiveness of enhancing learning processes. If faculty had this type of information in advance of teaching (or designing) their courses, then they could determine more effectively the type of learning assignments and activities that would be necessary to enhance the learning processes associated with working toward achieving the specific course outcomes.

An important question to address during the beginning stages of implementation of this conceptual framework is: Do we define the students as customers or the employers of the students as customers? This study assumes that employers are the customers and the educated student becomes the product. If this is the case, then stage one essentially means that the information gathering steps consist of obtaining factual data related to the raw materials that become part of the finished product.

For example, during the accounting program redesign project, the design team, in collaboration with the institutional research office, conducted a review of twenty years worth of student information for the entire student body. This information included data upon entry, such as high school GPAs, SAT scores, ACT scores, gender, age, ethnicity, religious affiliation, marital status, living residence, family income, and employment status. Cross tabulations of this information was reviewed by class levels and by declared major areas of study. Also included in this data gathering stage was information obtained through the dissemination of freshman surveys, student satisfaction surveys, graduating senior surveys, advising surveys and alumni surveys. It is important to note that this College had used national survey instruments for gathering the data which provided comparison group statistics as well as national norms, as opposed to designing their own internal surveys which provides limited information.

Reviewing factual data over the twenty year period provided design team members with knowledge about patterns and trends related to students classified by major. This information provided faculty with insight on the students they have, rather than the ones they may wish they had or thought they had. It is important to note that prior to obtaining the detailed information, the faculty had been engaging in an ongoing debate with the admissions staff in regard to statements that emphasized that they thought that the students that were admitted to their programs had changed over the years and therefore, the students were not meeting the performance expectations that faculty had desired. However, when the twenty year trends and patterns over time were reviewed, the information showed 
that the student data was consistent over time. Some interpreted this finding as an indication that the faculty perspectives about their student abilities had changed, while the students who enrolled in their courses were basically the same. Thus, stressing the importance of "teaching the students we have, rather than teaching the students we thought we had or wish we had." The information was valuable not only for thinking through how to structure activities and assignments within various courses, but also for thinking through how best to structure the delivery formats to best meet student needs. For example, faculty learned that most of their students were working full-time and/or part-time jobs, attending school full-time and commuting long distances to attend classes at the school. As a result of having this information, the faculty designed technology enhanced, accelerated evening and weekend program options, in addition to their traditional day based program to the meet the needs of those students who were working full time during the day. The following summary chart provides an overview of some of the information that was used to gain insight on the student population that enrolled at this particular College.

While there are many ways to define student markets, this chart defines them on the basis of the traditional trio of college markets: traditional, residential students; traditional, non-residential students; and adult students. These markets were originally defined irrespective of the delivery systems the College currently used or programs that it currently offered. The intention of this example is not to provide a definitive description of student markets. Rather, it is to provide a rationale for how to think about meeting students' needs with appropriate mixes of pedagogy, facilities, resources (human, information, and financial), and technology.

As noted in the chart, most of the Colleges' students had significant impediments - time, job and family responsibilities, and distance - to access to resources of all types. This means that for most of the students it was difficult for them to gain access to their faculty, to each other, to practitioners in their fields, library and other information resources, practitioners' tools, and so on. Most also would find it difficult to gain access to and participate in the College community as well. As noted in subsequent sections of this study, enabling access to resources of all types becomes crucial to taking positive advantage of the College's students' diversity, addressing the challenges posed by this diversity, and providing an applied liberal arts learning environment that meets the objectives included in the programs.

Another important finding from the information gathered during this stage of the process was that a minority of the College's students were interested in a classical liberal arts education, learning for its own sake, and the traditional developmental residential experience of living and learning in a college community. The data indicated that most were motivated by utilitarian interests in preparing for a career, advancing in a career, or changing careers. It was also likely that those interested in the classical liberal arts, residential experience were also motivated by utilitarian interests. In short, the College served markets that were, for the most part, interested in the "applied liberal arts," or, alternatively stated, they seek a liberal arts education they may use in the world of work. In keeping with their practical orientations, most of College's students were interested in convenience and efficiency in the pursuit of their degrees.

Even though the data collected indicated that most of the College's students did not seek to be actively engaged in the life of the College community, learning theory tells us that doing so would improve learning, and vast amounts of research tells us that the community as a whole would benefit from such engagement as would retention of individual students. So, regardless of what many students may say, the design team concluded that the students would benefit from greater engagement in the College community.

The design team also concluded that the College's markets were quite diverse along a number of dimensions which could significantly affect students' ability to learn, both positively and negatively. The findings also suggested that many of the students were not cognitively prepared for the programs they entered and that they required remedial work in one or more areas. Others students were noted to have language barriers to learning or were insufficiently mature to bring the motivation necessary for success to their work at the College. From a positive perspective, other dimensions of the College's students' diversity offered the opportunity for building upon the wide variety of life experiences, learning styles, and socio-cultural backgrounds that the students brought with them to the community by integrating learning with this variety. By creating linkages between student's biographies and learning in the applied liberal arts, each student gains. By developing mechanisms for sharing these linkages among students, all students gain. 
Table 1

Characteristics of the Student Market

\begin{tabular}{|c|c|c|c|}
\hline & $\begin{array}{l}\text { Traditional } \\
\text { Residential }\end{array}$ & $\begin{array}{c}\text { Traditional } \\
\text { Non-residential }\end{array}$ & Adult \\
\hline \multicolumn{4}{|l|}{ Seeking } \\
\hline \multirow{9}{*}{$\begin{array}{l}\text { Classical Liberal Arts } \\
\text { Personal/social development } \\
\text { Preparation for graduate/professional school } \\
\text { Preparation for entry into the workforce } \\
\text { Advancement in current career } \\
\text { Participation in the College community } \\
\text { Obtain an undergraduate degree } \\
\text { Obtain a graduate degree } \\
\text { Convenience/efficiency in obtaining a degree }\end{array}$} & Many & Some & Few \\
\hline & Most & Some & Few \\
\hline & Some & Some & Some \\
\hline & Most & Most & Some \\
\hline & Few & Few & Most \\
\hline & Most & Few & Few \\
\hline & All & All & Most \\
\hline & None & None & Some \\
\hline & Some & Most & All \\
\hline \multicolumn{4}{|l|}{ Characteristics } \\
\hline \multirow{8}{*}{$\begin{array}{l}\text { Age } \\
\text { Socio-cultural diversity } \\
\text { Gender diversity } \\
\text { Ethnic diversity } \\
\text { Citizenship/language diversity } \\
\text { Preparation for entry into program } \\
\text { Learning styles } \\
\text { Independent learner upon entry }\end{array}$} & $18-22$ & $18-25$ & $>25$ \\
\hline & Modest & Modest & Modest \\
\hline & Extensive & Extensive & Extensive \\
\hline & Modest & Modest & Modest \\
\hline & Modest & Some & Some \\
\hline & Mixed & Mixed & Mixed \\
\hline & Diverse & Diverse & Diverse \\
\hline & Few & Few & Many \\
\hline \multicolumn{4}{|l|}{ Employment } \\
\hline \multirow{3}{*}{$\begin{array}{l}\text { Part-time: < } 15 \text { hrs/wk } \\
\text { Part-time: > } 15 \text { hrs/wk } \\
\text { Full-time }\end{array}$} & Many & Few & None \\
\hline & Few & Many & Some \\
\hline & Few & Some & Most \\
\hline \multicolumn{4}{|l|}{ Family } \\
\hline \multirow{3}{*}{$\begin{array}{l}\text { Married } \\
\text { Children } \\
\text { Distance from main campus }\end{array}$} & Few & Some & Many \\
\hline & Few & Some & Many \\
\hline & On-Campus & Moderate & Distant \\
\hline
\end{tabular}

\section{STAGE TWO: COMPREHENSION OF EMPLOYERS' EXPECTATIONS}

The second stage in the conceptual framework process includes identification of broadly defined institutional outcomes and goals for students, determination of employers' expectations in the areas of knowledge and skills and interpretation of future employment statistics. As noted in previous sections of this paper, several studies have been conducted throughout the decades that provide examples of detailed skills sets, commonly referred to as work place know how or employability skills, which are deemed appropriate for preparing students to succeed in the $21^{\text {st }}$ century work environment. Rather than reinventing the wheel, over and over again, and incurring additional hours of work in this area which results in lower faculty productivity, it is imperative that business faculty integrate and build upon the skill sets that have been identified as relevant to the current and future workforce. This step results in identification of the outcomes, or destination to be achieved, which contributes to development of the course requirements that constitute a program.

The previous section described the student markets that the College served. This section provides a brief description of the learning outcomes that faculty want to achieve with their students. The following material is not intended to provide a definitive treatment of how a College would identify all of the learning outcomes it might wish to achieve with its students. Rather, it is intended to provide a summary tool to stimulate thinking about learning outcomes. It also provides a mechanism for identifying the ways in which appropriate combinations of pedagogy, resources, and technology may be used to address students' learning needs. 
It is important to note that at most small, private Colleges a set of cross-curricular learning outcomes and the abilities associated with them are either expressly identified or suggested by the College's Core Curriculum and/or distribution requirements. In each case ability may be used to think critically, create, and/or communicate with general or specialized audiences. Also in each case ability may be viewed as an end in itself (a learning outcome) and/or as a means to perform an assignment designed to achieve a discipline or content-based learning objective. It is also important to note that, while some abilities may have specific courses devoted to them, for the most part students develop these abilities by using them and reflecting upon them in their work across the curriculum. Alternatively stated, students develop these abilities while using them to do assignments that faculty design to enhance them (either as an end in itself or by requiring their use to complete the assignments) and from their instructors' evaluation and assessment of their work.

It may be useful here to foreshadow the treatment of the relationship between cross-curricular learning outcomes and the selection and use of digital tools to enhance their achievement and use in learning. For example, the accounting project design team identified the learning abilities listed below to use as a template for determining what software and hardware a college should provide its students and faculty and help it organize its human resources to make the most effective use of it investments in technology. Finally, the short-hand technique used below for listing learning abilities is sufficient at this stage in the conceptual framework because the formal language of learning outcomes is determined during subsequent steps in this process. The purpose of the list below is to provide a summary of the most common expected employability skills or basic fundamentals of work place know how.

\section{EXAMPLES OF BROADLY DEFINED EMPLOYABILITY OUTCOMES}

Reading
Writing
Quantitative reasoning
Causal reasoning
Information literacy
Determining relevancy of information to problem-solving
Using information to inform decision-making
Critical thinking
Listening
Speaking
Discussion
Role playing
Presenting
Visualizing
Synthesizing
Teamwork and collaboration
Leadership
Application of theory in practice
Understanding the relationships among multiple disciplines' content, theories, and methods
Cultural literacy
Appreciation of diversity in all of its dimensions
Participating in and contributing to community
Time, resource, and project management
Self-reflection
Learning to learn to engage in life-long learning
Leading an ethical life
An understanding of how one's knowledge and abilities apply to one's educational, career, and life
objectives
In addition to summarizing employer's general expectations regarding learning outcomes, the design team
-


broadly applicable disciplinary knowledge and learning abilities that would apply to essentially all disciplines taught at the College. This step resulted in the creation of a summary chart or tool that could be used by other faculty outside of the business department. This list appears below. As with the employability list of learning abilities suggested in the previous section, the following list could be used to suggest strategies for investing in and making the most effective use of software, hardware, and other digital resources.

\section{EXAMPLES OF BROADLY DEFINED DISCIPLINARY LEARNING OUTCOMES}

- Knowledge of the discipline's cannon of core concepts, their history, and how they relate to each other

- Knowledge of the discipline's core literature, how to gain access to it, and how to use it

- Knowledge of and the ability to use the discipline's

- Theoretical perspectives

- Methodologies

- Base of current knowledge

- Tools

- Resources

- $\quad$ An understanding of the discipline's language, conventions, and norms

- A understanding of the discipline's standards of professional and ethical behavior and of any regulations that may apply to practicing the profession

- $\quad$ Applying theory with appropriate methods to unstructured, authentic situations

- Understanding the relationship of the discipline to other disciplines related to it

- Ability to learn independently in the discipline to engage in continuous life-long learning

- Knowledge of how the discipline is organized, who contributes to it, and its professional associations

- Appreciation of the discipline's historical development

- An understanding of how the discipline has contributed to society and been affected by it

- An understanding of how one's knowledge and abilities apply to one's educational, career, and life objectives

In addition to obtaining information about employers' expected skill sets and faculty's disciplinary skill sets, it is also important to investigate current and future employment projections. This step in the process helped the design team to determine which business programs would be the most effective in addressing their students' needs for those who are continually seeking employment within the local community. Previous research in this area referenced this process as gap analysis which focused primarily on an analysis of national employment projections (Phelps and Kimball, 1994; Phelps, Aggarwal, and Taylor, 2006). However, this study recommends an extension of this analysis to include regional and local employment projections because these projections may vary when compared to national projections. Extending this analysis in this fashion is necessary, especially for the small, private, independent College sector. A primary, reason for this extension is that schools in this sector usually have a significant number of students classified as commuter students (this characteristic is recognized during the first stage of the framework when identifying characteristics of the student body). The commuter population of students generally elects to attend a particular educational institution that is within close proximity to either their place of employment or their place of residence. More importantly, during the admissions and/or advising processes, these students typically indicate that they can not (or will not) relocate upon graduation. Therefore, an analysis of the local and regional employment projections are extremely important to meet the needs of these students. For example, if Cleveland, Columbus or Cincinnati, Ohio, is the location of a particular College, then a review of the 2004 to 2014, U.S. Department of Labor's Occupational Employment Projections Handbook indicates that national statistics are different from local, regional and state based statistics. As noted in the following summary comparison charts, the growth rate and number of job openings within the occupational groups vary by geographical location. 


\section{SUMMARY COMPARISON OF U.S. DEPARTMENT OF LABOR'S EMPLOYMENT PROJECTIONS FOR 2004 TO 2014}

\begin{tabular}{|l|c|c|c|c|c|c|}
\hline $\begin{array}{l}\text { Employment Projections } \\
\text { 2004 to 2014 }\end{array}$ & $\begin{array}{c}\text { NAT } \\
\text { Job Categories } \\
\text { by Number of Annual New Jobs }\end{array}$ & & $\begin{array}{c}\text { OH } \\
\text { (in } 000 \text { 's) }\end{array}$ & $\begin{array}{c}\text { OH } \\
\text { OH }\end{array}$ & $\begin{array}{c}\text { OH } \\
\text {-COL }\end{array}$ & $\begin{array}{c}\text { OH } \\
\text {-CIN }\end{array}$ \\
\hline Accountants and Auditors & 486 & 1654 & 189 & 404 & 325 & 280 \\
\hline Marketing, Advertising/Sales Managers & 249 & 47 & 12 & 31 & 28 & 48 \\
\hline Management Analysts & 204 & 484 & 45 & 116 & 169 & 152 \\
\hline Financial Managers & 154 & 337 & 36 & 83 & 77 & 111 \\
\hline Chief Executives & 150 & 475 & 53 & 82 & 85 & 151 \\
\hline Financial Analysts & 151 & 161 & 17 & 55 & 28 & 21 \\
\hline Computer and IT Managers & 124 & 333 & 27 & 71 & 108 & 98 \\
\hline Construction Managers & 123 & 343 & 37 & 65 & 84 & 116 \\
\hline Real Estate Managers & 123 & 73 & 12 & 13 & 19 & 63 \\
\hline Agriculture Managers & 109 & 64 & 6 & 7 & 9 & 9 \\
\hline Medical/Health Services Managers & 105 & 371 & 44 & 85 & 74 & 95 \\
\hline Food Service Managers & 103 & 391 & 45 & 75 & 92 & 134 \\
\hline Administrative Services Managers & 97 & 218 & 23 & 58 & 48 & 77 \\
\hline Engineering Managers & 63 & 180 & 20 & 35 & 27 & 41 \\
\hline Personal Financial Advisors & 61 & 172 & 27 & 22 & 38 & 46 \\
\hline Social/Community Service Managers & 60 & 133 & 11 & 30 & 24 & 28 \\
\hline HR/Labor Relations Managers & 58 & 153 & 7 & 28 & 26 & 45 \\
\hline Tax Agents, Examiners & 45 & 76 & 9 & 13 & 20 & 68 \\
\hline Industrial Production Managers & 32 & 156 & 19 & 34 & 20 & 31 \\
\hline Purchasing Managers & 21 & 61 & 10 & 15 & 8 & 22 \\
\hline Lodging Managers & 19 & 41 & & 7 & 13 & 8 \\
\hline Budget Analysts & 17 & 45 & & 9 & 16 & 9 \\
\hline Natural Sciences Managers & 14 & 24 & & 5 & 6 & 13 \\
\hline Credit Analysts & 13 & 44 & 4 & 20 & 19 & 10 \\
\hline Funeral Directors & 10 & 55 & 6 & 6 & 3 & 6 \\
\hline
\end{tabular}

The final step in this stage of the conceptual framework is to combine the knowledge gained from the list of employer related outcomes, the list of disciplinary outcomes and the statistics of employment projections to determine the program specific goals and objectives. For example, continuing on with the accounting program redesign project, a review of future employment projections indicated that the growth rate in the accounting, information systems and business management related professions would continue to be strong and the Bureau of Labor Statistics projected a 22 to 26 percent increase in job openings during the next the decade. This growth rate reflected the increasing complexity of corporate transactions and the growth in government reporting regulations. The design team also learned that many diverse opportunities would be available for accounting related professionals, according to the American Institute of Certified Public Accountant's report on "The Supply of Accounting Graduates and the Demand for Public Accounting Recruits". It is also important to note that the majority of states now have laws which require a fifth year of education to become a certified public accountant. This change reflects a more competitive business environment and increasing skills requirement because of the rising complexity of global operations. 


\begin{tabular}{|l|c|c|c|c|c|c|}
\hline $\begin{array}{l}\text { Employment Projections } \\
\text { 2004 to 2014 }\end{array}$ & NAT & OH & $\begin{array}{c}\text { OH } \\
\text { Job Categories by Growth Rate }\end{array}$ & $\begin{array}{c}\text { OH } \\
\mathbf{- C L E}\end{array}$ & $\begin{array}{c}\text { OH } \\
\text {-COL }\end{array}$ & $\begin{array}{c}\text { OH } \\
\text {-CIN }\end{array}$ \\
\hline Personal Financial Advisors & 25.9 & 26.1 & 26.9 & 29.4 & 31.4 & 32.0 \\
\hline Computer and IT Managers & 25.9 & 19.6 & 17.1 & 19.8 & 26.4 & 21.3 \\
\hline Social/Community Service Managers & 25.5 & 16.3 & 15.6 & 14.4 & 11.4 & 12.8 \\
\hline Medical and Health Services Managers & 22.8 & 15.4 & 16.4 & 25.4 & 21.9 & 28.1 \\
\hline Accountants and Auditors & 22.4 & 13.6 & 16.9 & 12.5 & 16.0 & 17.6 \\
\hline HR/Labor Relations Managers & 20.3 & 16.4 & 13.6 & 9.2 & 14.1 & 11.4 \\
\hline Advertising, PR and Sales Managers & 20.3 & 14.9 & 13.5 & 10.0 & 18.7 & 10.9 \\
\hline Management Analysts & 20.1 & 11.1 & 13.1 & 21.0 & 27.5 & 37.5 \\
\hline Financial Analysts & 18.2 & 14.2 & 12.9 & 15.4 & 14.7 & 9.2 \\
\hline Administrative Services Managers & 16.9 & 14.0 & 17.2 & 14.5 & 12.9 & 14.7 \\
\hline Lodging Managers & 16.6 & 10.6 & & 6.5 & 10.9 & 9.4 \\
\hline Property and Real Estate Managers & 15.3 & 8.1 & 9.5 & 20.6 & 20.8 & 30.5 \\
\hline Chief Executives & 14.9 & 9.5 & 8.9 & 7.4 & 13.4 & 12.7 \\
\hline Financial Managers & 14.8 & 9.8 & 12.7 & 8.5 & 12.5 & 12.1 \\
\hline Natural Sciences Managers & 13.6 & 8.1 & & 11.1 & 10.5 & 22.6 \\
\hline Budget Analysts & 13.5 & 8.1 & & 14.3 & 5.5 & 8.1 \\
\hline Engineering Managers & 13.0 & 6.2 & 6.8 & 1.9 & 7.1 & 4.9 \\
\hline Food Service Managers & 11.5 & 8.4 & 10.0 & 12.7 & 15.7 & 16.9 \\
\hline Construction Managers & 10.4 & 10.2 & 12.3 & 17.5 & 19.9 & 25.0 \\
\hline Tax Agents/Examiners & 8.0 & 3.9 & 10.7 & 1.9 & 5.7 & 8.9 \\
\hline Purchasing Managers and Buyers & 7.0 & 0.0 & 2.4 & -4.3 & -2.8 & -1.0 \\
\hline Funeral Directors & 6.7 & 3.5 & 0.0 & -5.0 & -9.1 & 0.0 \\
\hline Credit Analysts & 3.6 & -1.1 & 0.0 & 8.3 & 14.8 & 6.8 \\
\hline Industrial Production Managers & 0.8 & -3.5 & -2.0 & -2.8 & 3.3 & -1.2 \\
\hline Agriculture Managers & -11.3 & 0.3 & 0.0 & -7.1 & -7.4 & -18 \\
\hline
\end{tabular}

\section{EXAMPLES OF PROGRAM GOALS AND OBJECTIVES}

When implementing stage two of the framework process, the collaborative design team members, who worked on the accounting program design project, identified a minimum level of skills which defined what the graduates from the program should know and be able to do upon graduation. The first step in the process was to incorporate the institutional outcomes and goals for students into their program specific set of outcomes. The program specific outcomes were obtained from professional associations, business accreditation agencies, national statistics and research studies that assessed employer expectations for College graduates.

The next step was to define the programs mission, goals, and objectives. The faculty decided to revise the title of the program from accounting to accounting information systems (AIS) in order to reflect the integrative cross-functional nature of the redesigned program and to reflect the technological advancements that were occurring within the information systems area. The program's revised mission statement was to enhance students' knowledge, skills, dispositions, and values to pursue meaningful professional careers and/or graduate studies by delivering a high quality, interdisciplinary, competency-based educational program in accounting information systems. This mission was guided by the College's mission statement which includes the basic fundamentals of a strong liberal arts foundation.

To work toward achieving the program's mission, the following three broad-based program goals were developed: 
- $\quad$ to challenge students to develop a capacity for 'learning how to learn', not only for knowledge, but for understanding, for meaning, and for purpose by building on both the liberal arts foundation and the interconnected educational experiences in accounting, business, and information systems;

- $\quad$ to develop students' knowledge, skills, dispositions and values associated with the learning outcomes of reasoning, communication, collaboration, reflectivity, and information technology; and

- $\quad$ to introduce students to real-world unstructured decision making and problem solving processes involving both qualitative and quantitative information through completion of a variety of assignments (learning activities) that include independent work, paired work, and team work projects.

After defining the broad based program goals, the next step in the process was to determine the program level objectives that would assist faculty in working toward achieving the program goals.

The program objectives were identified as follows:

- $\quad$ to develop a student's understanding of accounting as a broad information discipline that includes international, ethical, and social perspectives;

- $\quad$ to develop a student's proficiency in the application of accounting theory to unstructured real-world problem solving and decision making;

- to develop a student's knowledge, skill, and ability to think critically, analytically, and logically when solving problems and analyzing relevant information for decision making;

- $\quad$ to develop a student's knowledge, skill, and ability to interpret and express insights, truths, and values when preparing oral and written communication from an accounting perspective;

- to develop a student's knowledge, skill, and ability to collaborate with a culturally diverse group of team members when solving problems or making decisions to achieve common goals;

- $\quad$ to develop a student's knowledge, skill, and ability to use appropriate technology in locating, retrieving, organizing, evaluating, synthesizing, and disseminating relevant information for problem solving and decision making;

- $\quad$ to develop a student's knowledge, skill, and ability to exercise productive habits of mind to facilitate selfreflection through investments in life long learning; and

- $\quad$ to develop a student's knowledge, skill, and ability to use technology as an effective and efficient life long learning tool.

\section{STAGE THREE: DETERMINATION OF BEST PRACTICES}

Stage three of the conceptual framework process involves a determination of best practices which consists of reviewing other schools who offer business related programs. Previous research studies in benchmarking only highlight conducting an investigation of those institutions that have a similar mission to obtain insight on best practices. This study stresses the importance of extending this investigation to include at least four different comparison groups to ensure a thorough and complete review of best practices. This step involves not only looking at schools with similar missions and visions, but also reviewing schools in an aspirant group and competitor group. This approach is more realistic and similar to practices in the corporate world because some consumers buy products or services regardless of the similarities or differences that exist among competitors' mission statements.

The first step in the benchmarking process would be to conduct a random sample of 1) a group of similar schools using the Carnegie classification system 2) an aspirant group developed internally; 3) a national/international group of AACSB accredited schools; and 4) a local competitor group within a 45 to 60 mile driving radius. It is interesting to note that a typical response by faculty within the small, private independent sector is that they only include in the competitor analysis schools that have a similar mission. However, this study highly recommends that when working with a large number of commuter students, all schools within a reasonable driving range, from either their work location and/or their place of residence, becomes a potential competitor in which the students may determine as their College of choice. This means that the competitor group should include all schools within geographical proximity, regardless of the differences or similarities associated with mission statements. 
For example, in the accounting program project, information was gathered on best practices from 150 Colleges and Universities. The design team created a spreadsheet summary of the similarities and differences that existed among the business related programs of all of the schools in the comparative lists. They identified patterns and trends of curricular related elements to establish best practices benchmarking information. Interestingly the findings of this step in the process indicated that most of the schools within the small, private, independent sector of higher education, rather than the larger, elite research flag ships schools, were applying innovative curricular development initiatives that addressed both relevance and quality of business program design efforts.

\section{STAGE FOUR: ANALYSIS OF THE GAPS}

The fourth stage of the conceptual framework process is to conduct a gap analysis. In contrast to previous studies, this study defines gap analysis as an evaluation of the information obtained thus far in the previous three stages of the conceptual framework. More specifically, the purpose of this step is to analyze the existing learning path associated with the curriculum requirements of an existing program to determine the holes or gaps that exist among best practices information, employer expectations' of skills sets, employment projections and student body characteristics. Applying gap analysis in this manner provides insight on how to determine the distinctive benefits that should be incorporated into the program. The result of this investigation provides information about the courses and/or programs that should be revised and/or developed, as well as insight on the internal course linkages defined as course prerequisites. This step includes preparation of a visual diagram that serves as an analysis of the existing learning path for students as they progress from start to finish for a particular major, along with the revised or enhanced learning path that must be implemented in order to work toward achieving best practices in program development. The information gleamed from these activities also sheds light on the next stage of the conceptual framework which focuses on the determination of pedagogical methods and strategies that should be integrated within various courses (such as active, rather than passive learning strategies).

For example, the following diagrams provide a visual summary of the existing and revised learning paths for the accounting program redesign project. As noted in the diagrams, when comparing the existing learning path to the revised learning path, the design team not only developed new cross functional courses for the program, but also revised the internal curricular linkages of the course prerequisite structure. For example, faculty learned that students' who had matriculated into the accounting major had weak foundational mathematical abilities. The previous existing structure listed math as a required course, but did not explicitly require the course as a prerequisite to any other courses that were required within the major. A review of student audit sheets during the advising and registration process indicated that most of the students were not taking the math course until their senior year or final year of study. The faculty members determined that the required math course was instrumental to a student's success in their accounting, finance and economics courses. Therefore, they significantly revised the prerequisite structure which included the math course as a prerequisite for providing fundamental foundational knowledge of mathematical concepts that the faculty would build upon in their accounting, finance and economic courses. A similar strategy was used in the area of identifying student weaknesses in the area of critical thinking, oral communication and written communication. Thus faculty revised the prerequisite structure to create explicit internal course linkages that required four of the College's core curriculum courses (i.e., two English and two Humanities courses) as prerequisites to their business related courses because it was determined in consultation with faculty who taught in other disciplinary areas that these courses provided the foundational knowledge and skills in the critical thinking and communication areas.

Overall, faculty members found that the process of preparing the learning path diagrams helped them to obtain a more holistic perspective on program development, rather than a piecemeal understanding of how a student progresses through completion of the course work required in a program. The diagrams also provided a visual analysis that emphasized the importance of creating explicit internal linkages among courses to strengthen the foundational structure for which upper level courses are built upon. The most important message gleamed from the visual diagrams below is that this process enhanced and strengthened internal linkages as shown by the "arrow based connecting rods". 


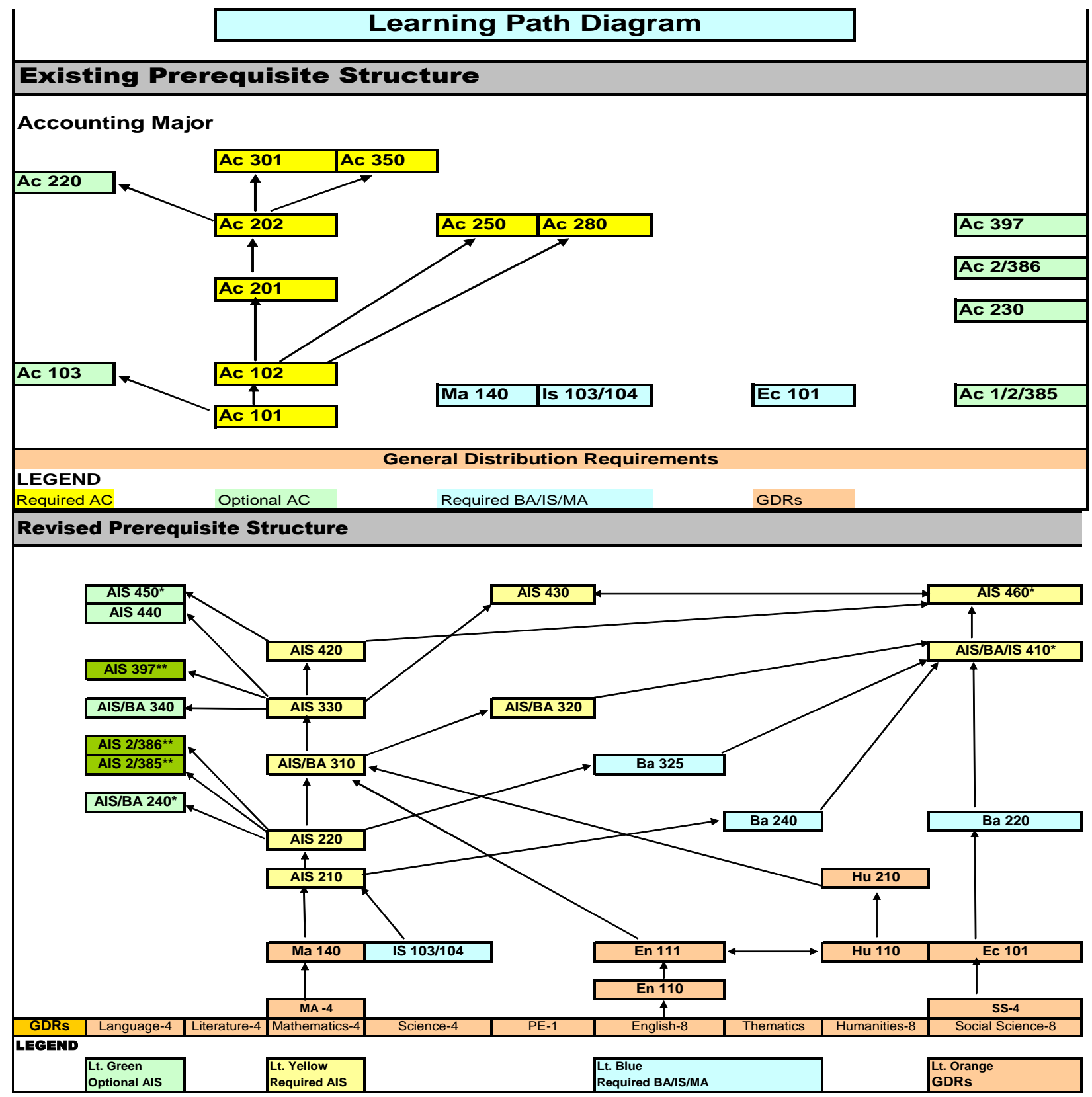

\section{STAGE FIVE: SYNTHESIS OF ELEMENTS}

The fifth stage of the conceptual framework is to determine the types of learning activities and pedagogical strategies that will be used within the courses that constitute the program. This process includes a synthesis of the information gathered from the previous four stages of the conceptual framework. As noted in stage four, the learning path of the program is revised or enhanced based on gap analysis, which not only includes new course development or course revisions, but also includes modifications to prerequisite course structures. The next step is to determine what activities should take place within each course to ensure that the program level outcomes are being achieved. During this step of the process the design team determines the specific list of detailed learning outcomes for each course. The design team also collaborates on the development of assignments and activities that will be used in each 
course. Once the outcomes and assignments have been established, faculty must determine an appropriate set of pedagogical strategies to use to maximize the learning process within each course. An appropriate question to ask at this stage in the process is: what type of learning approaches should be used to ensure that business courses are relevant in meeting employers' expectations while simultaneously addressing the diversity of learning styles of students? Or how do we design instructional processes to ensure that students achieve the learning outcomes?

Unfortunately, some business faculty will respond to this question that they will continue to teach in the same manner as they have always taught or they will continue to teach the way that they were taught, rather than seizing the opportunity to think through new, innovative or more effective teaching strategies. Interestingly, most higher education business faculty members are hired to teach based on their academic credentials in a business related field and most, if not all, did not receive formal training on how to implement effective teaching methods during the completion of their business related academic degrees.

This study suggests that this stage in the process is a critical success factor for achieving effective program design efforts because faculty need to make sure that they incorporate, into each of their courses, best practices in both teaching and learning. As previously noted a plethora of research suggests that learning processes are maximized when faculty focus on active, rather than passive learning (Razzouk, Seitz and Rizkallah, 2003). Emerging research in the field of cognitive science focuses on how knowledge is acquired and used and its research findings challenge what we teach and when and how we teach it. For example, these results challenge faculty traditional distinctions between: knowing and doing, abstract and applied knowledge, school-based and work-based learning. Research in this area concludes that educators often depict learners as passive receptacles into which knowledge may be poured, skills are often taught in isolation and that learners get little practice in applying and combining skills. Most importantly, their studies also reveal a surprising lack of transfer of theoretical principles, processes, or skills learned in classes to practice (Tabor, 2005; Young, 2002; Elliott and Goodwin, 1994). Cognitive science strongly implies that people learn best when they are taught in the context of situations, activities, and problems. Learning in context provides meaning and therefore motivation to learn (Resnick, 1987). It helps to break down the separation between knowledge (knowing) and practice (doing) that has resulted from the formal approach to instruction in schools and the resulting mismatch between school and work (Lave, 1998; Razzouk, Seitz and Rizkallah, 2003; Resnick, 1987).

It is important to note that the nature of the cross-curricular and disciplinary learning outcomes listed in the previous sections suggest a particular approach to developing pedagogical strategies that would be effective in achieving them. Unfortunately, there is a tremendous amount of rhetoric and jargon embedded in discussions of effective pedagogy. Fortunately, there is an excellent summary of the research on effective practices in teaching Seven Principles of Good Practice in Undergraduate Education (Chickering and Gamson, 1987). These principles do an excellent job of summarizing the literature on effective pedagogy and provide a very practical framework within which one may create linkages among the characteristics of a College's student markets, cross-curricular and disciplinary learning outcomes, and the effective use of digital resources to enhance students' achievement of learning outcomes. For example, the accounting design team used the following list as best practice guidelines for pedagogical instructional methods associated with designing activities and assignments for each course.

Seven Principles of Good Practice in Undergraduate Education (Chickering and Gamson, 1987)

1. Good Practice Encourages Contacts Between Students and Faculty

2. Good Practice Develops Reciprocity and Cooperation Among Students

3. Good Practice Uses Active Learning Techniques

4. $\quad$ Good Practice Gives Prompt Feedback

5. Good Practice Emphasizes Time on Task

6. Good Practice Communicates High Expectations

7. Good Practice Respects Diverse Talents and Ways of Learning

When thinking through which best practices in teaching and learning to use, it also is important to address another set of very important pedagogical issues regarding learning styles because they are strongly related to the 
Seven Principles and the use of effective pedagogy to achieve the cross-curricular and disciplinary learning outcomes.

For over a decade, Howard Gardner has been developing the theoretical framework and experimental data to support the position that individuals posses multiple intelligences, or ways of knowing. Over this same period, the results of his and others' work in this domain have filtered into mainstream education with the label of "learning styles." (For example, see the seventh of the Seven Principles above.) If faculty members are to achieve the learning outcomes they decide to adopt, then addressing multiple learning styles and impediments to learning in its pedagogical strategies will be necessary.

The seven learning styles that Gardner has identified are: Logical/mathematical; Linguistic; Visual/spatial; Aural/musical; Knowledge of self; Knowledge of others; and Kinesthetic (Gardner, 2000; Scherer, 1999). It is important to note that many business faculty members have been educated in systems that emphasized, almost exclusively, logical/mathematical and linguistic learning styles. Yet many individuals learn best using their other five intelligences. However, the importance of this observation has become greater as higher education has opened its doors to a much more diverse population of students. Many small Colleges are now confronted with populations of students who have successfully completed high school without strong logical/mathematical and linguistic intelligences. The challenge, then, is to tap students' other "learning-style" strengths to master content and develop their abilities while simultaneously helping them develop their logical/mathematical and linguistic intelligences that are necessary for the achievement of many of the learning outcomes described above and for constructive participation in a career and in society at large. The larger challenge is to do this in a "personalized, individuallyfocused education" which is part of the College's mission and vision.

An example may prove useful here. Mastering college algebra is a major challenge for many students because they are weak with respect to their logical/mathematical intelligence which depends upon symbolic representation of abstract concepts. However, many of these same students have relatively strong visual/spatial and aural/musical intelligences. A technological tool such as Mathematica with well-designed assignments would enable these students to explore algebraic concepts visually (through graphs) and aurally so they could master the concepts while simultaneously developing their abilities to understand the concepts' symbolic representations. A subsequent section provides additional examples of how to build upon students" "multiple intelligences" strengths while helping them rectify their weaknesses.

Gardner's work on multiple intelligences provides a framework for implementing pedagogical strategies consistent with the Seven Principles as well as guidelines for how business faculty might actually achieve the goal of providing personalized, individually-focused education. The challenge is to employ the Seven Principles while tapping each student's strengths with respect to learning styles while rectifying their weaknesses.

In addition to his work on multiple intelligences, Gardner has identified three major impediments to learning that humans develop during their early years of maturation prior to exposure to formal, disciplinary-based ways of understanding the world in high school and college. These impediments usually go undetected because, even though they exist, students may still perform well on tests that do not assess true or fundamental understanding of concepts covered by a test (e.g., the student may simply parrot back the answers from the lecture or the textbook).

The three primary impediments to learning that Gardner has identified are: private theories, algorithmic thinking and stereotypes (Gardner, 2000). Children develop private "theories" of how the world works so they can make sense of the world. Gardner and others have demonstrated that these private theories are extremely difficult to dislodge. For example, they have demonstrated that many Harvard students, who have done well in college physics, revert back to their private theories of how the solar system "works" after they complete the course. Many MIT graduates, who have done well in their coursework, revert back to their private theories upon graduation and find that they cannot apply what they learned in college to unstructured, real-world engineering problems. Similar results have demonstrated the strength of private theories regarding historical events, social interactions, and so forth. 
Algorithmic thinking is another vexing challenge that prevents students from developing their ability to apply what they have learned outside the artificial context of a test. The quintessential example of this problem is the student who masters the mathematical strategy (algorithm) for solving a certain type of textbook problem but does not master the mathematical ability to solve unstructured, real-world problems that require the use of the underlying concept.

The third impediment to learning, stereotypes, often yields similar negative results in the social sciences and the humanities. Gardner and others have demonstrated that cultural, ethnic, religious, and other stereotypes frequently lie just beneath the surface throughout a student's educational career and re-emerge upon completion of a course or upon graduation. Students learn to provide the "right answer" on the tests they take and the short essays they write, but still harbor the stereotypes they learned as children. This is a particularly vexing issue for the small, private, religious affiliated Colleges because they place such importance on values-based learning and holistic student development.

A required first step toward addressing these three impediments to learning, in the context of the learning outcomes described above, is to implement pedagogical strategies consistent with the Seven Principles that incorporate effective use of students' multiple intelligences. However, this is just the first step. The necessary second step is to design assignments and associated assessment strategies that require students to go beyond the "right answer" so that they are engaged in authentic (real world) tasks appropriate to the learning outcome being addressed. This will enable a student's instructor to discover how a student's private theories, algorithmic thinking, and stereotypes are affecting his or her learning and enable the development of strategies to overcome these impediments with the student. Alternatively stated, assessment of this type is "assessment as learning" for the student and instructor to discover the student's private theories, algorithmic thinking, and stereotypes. Once discovered, the student and professor can reflect upon them and together make progress toward enabling the student to develop mastery of a discipline or concept. The section below regarding assessment will provide additional suggestions for accomplishing this goal.

\section{STAGE SIX: EVALUATION OF PROGRAM COMPONENTS}

The final stage of the conceptual framework is to create formal assessment processes to provide a feedback mechanism for continual improvement. This step creates the feedback connecting rod that links the conceptual framework process back to stage one, so that the model provides a continual circular loop of effectiveness.

When all is said and done, program development efforts are means toward an end, not ends in themselves. The "bottom line" of program development initiatives should be improved student learning for significant numbers of students in significant areas of learning. Alternatively stated, no matter how well faculty participants rate the program, if their students' learning does not improve, then the program was not a success. So, how will the College know whether its program has succeeded? How will it know which strategies work with which students? How will it know which strategies did not succeed? How will it know how to improve them? These are very difficult questions, questions that have been plaguing higher education for decades. But, before suggesting answers to them, the next section describes what these questions are not about.

These questions are not about the types of institutional and program assessments that are typically raised by accrediting agencies. They are not about gathering information periodically to justify what one is doing for these and similar external agencies. They are not about eliciting students' opinions about whether their learning has improved. They are not about student satisfaction. Well, if they are not about these issues then what are they about?

They are about whether students' learning is improving. They are about gathering practical, actionable information faculty may easily use on a regular (even continuous) basis to learn what is working and why with whom, what is not working and why with whom, and what they can do to improve their students' learning through improving their teaching. Put in this light, these questions are about what has come to be called the "scholarship of teaching." Simply stated the scholarship of teaching is a habit of mind that leads to using the rigor associated with disciplinary scholarship applied to the teaching/learning process (Boyer, 1990). There is no single, best way to 
engage in the scholarship of teaching. Rather, there are many strategies that faculty may adapt to their own needs and the needs of their students. What they all have in common, however, is that assessment seen in this light leads to learning about teaching and learning both for the faculty member and the student.

Since this topic is usually highly controversial and subject to gross misinterpretations among people of good will, this study does not attempt to address all of its ramifications. For that matter, even making a minimal attempt to do so would take a paper in itself. However, this study does attempt to provide some guidelines for addressing this complex issue. Probably the most important piece of advice to give in this area is to start small, but start. Do not debate all the issues. Do not attempt to find the best way to assess teaching and learning. Do not attempt to satisfy everyone's objections. Rather, pick some simple tools that work, start using them, and learn from the collective experiences.

Following from this is the recommendation that the design team should include tools faculty may use to assess progress in each of the substantive areas recommended above. One should not expect student learning to improve simply from training faculty in the basics of technology. However, student learning should improve as a result of your efforts in the pedagogy, discipline/course specific learning outcomes, and core course initiatives. The design team should also help faculty learn to use these tools. And they should create an environment that encourages a culture of assessment to emerge from their efforts. This means encouraging faculty to routinely share and discuss with each other what they are learning about their teaching and learning from their "scholarship of teaching." Here are two suggestions for practical resources to use to get things started.

The following information is from the Wiley Publishers web site that describes their Jossey-Bass publication of Patricia Cross' and Mimi Harris Steadman's Classroom Research: Implementing the Scholarship of Teaching. (http://www.wiley.com/cda/product/0,,0787902888,00.html). This text, along with companion pieces, provides a set of very practical, relatively easy to implement methods for assessing student learning and finding out what works and what doesn't. One strategy to use is to purchase copies of these resources for members of the design team so they may adapt these methods to the needs of College's faculty. Also note in the description below the emphasis upon engaging faculty in a cooperative effort to learn what works and what does not.

Classroom Research is the eagerly awaited "next step" resource to Thomas A. Angelo and K. Patricia Cross's bestselling guide, Classroom Assessment Techniques. Classroom Assessment Techniques offers faculty members a set of tools to identify what is working and what is not in their classrooms and the companion volume Classroom Research details a collaborative process for investigating teaching and learning issues. This technique engages teachers in problem-based discussions, integrates their teaching experience with recent research and theory on learning, and gives examples of Classroom Assessment and Classroom Research projects that can be carried out in any classroom. It provides a pathway into "the scholarship of teaching." Designed to be used by faculty members in groups and in workshops, Classroom Research's case method approach illustrates ways to think about a variety of common learning issues. The cases show students in the process of learning, clearly illustrate their problems and perceptions, and focus on long-term issues such as memory, motivation, deep and surface learning, metacognition, learning strategies, gender issues, intellectual development, and critical thinking. The authors designed the discussion questions to provoke a lively exchange of ideas and interpretations and they show how faculty can acquire the critical knowledge-from research and literature as well as from students themselves-to determine some possible solutions.

Another set of resources to pursue was created by the Flashlight Project. Extensive information may be found about this project at http://www.tltgroup.org/programs/flashlight.html. What is important to convey here is that this project was designed to provide assessment tools tied directly to the Seven Principles of Effective Practice in Education. These resources include: (1) an item bank of questions faculty may use to construct questionnaires to determine the extent to which their students are engaged in activities consistent with each of the Seven Principles; (2) strategies for using questionnaires to determine the extent to which an instructor's attempts to encourage "Seven Principles" behavior are successful or not and why with which students; and (3) strategies for acting on the information gathered using Flashlight tools to rectify problems and build on successes. A license to the Flashlight materials costs approximately $\$ 700$ and would provide the entire College with access to the current Flashlight 
materials and any new materials that are added over the twelve month period of the license. After that period a College would be able to continue to use the materials obtained during the license period indefinitely.

As indicated above, there are many ways to approach the assessment issue. Additional resources and some other strategies may be located at http://two.merlot.org, the MERLOT project's web site for faculty development personnel. This study concludes that the important point is to start, start small, integrate assessment strategies in all of the program related design initiatives, encourage discussion, cooperation and collaboration among faculty about what they are learning from their scholarship of teaching, and then build on the collective knowledge base developed over time. The end result is that the College will soon be able to gauge the learning return on investment of time, effort, and money in faculty development and support and the digital resources you have invested in.

\section{CONCLUSIONS}

In closing, this study addressed the most common criticisms that have transpired throughout the decades in regard to both the relevance and quality of business programs. Some of these criticisms emphasized that educational programs have not been revamped adequately to address the constantly changing needs of the workplace, especially when considering the impact of globalization and technology. It was important to note that these criticisms were not only related to business programs, but also were related to our educational systems in general. This study suggested that a certain segment of the higher education industry, the small, private College sector, is on target in preparing their students to succeed not only in the world of work, but also in the world of living. This suggestion was supported by concrete examples of how faculty at a small, private College implemented a conceptual framework program design process to redesign one of their business related programs. This model emphasized that to meet the constantly changing needs of employers, business professors must build programs that enable each student to achieve the unique combination of industry, disciplinary and cross-disciplinary performance standards (learning outcomes) appropriate to a give sector of the economy through the integration of best practices in life-long learning and continuous quality improvement. To build the bridges that "connect the disconnects", business professors and local businesses must work together as part of a collaborative design team to create business programs that effectively prepare the workforce for the $21^{\text {st }}$ Century.

Dr. Debra L. Fleming, CPA, is professor of accounting and management and Executive Director of Business Programs at Ursuline College.. Dr. Fleming has over ten years of administrative experience in higher education which includes having served as Dean of the School of Business at Dowling College, Associate Vice President for Academic Affairs and Vice President of Learning, Assessment and Technology at Centenary College, and as Assistant Provost for Institutional Effectiveness and Research at Palm Beach Atlantic University. She also served as an accounting professor for thirteen years at Ohio Dominican University and as an adjunct professor for seven years at Ohio State University. She has over twenty two years of teaching experience as a business professor and ten years of experience as a national consultant on technology.

\section{REFERENCES}

1. Adams, A. \& Hancock, T. (2000). "Work experience as a predictor of MBA performance." College Student Journal, 30(2), pp. 211-216.

2. Alford, H. and Naughton, M. (2001). Managing as if Faith Mattered (University of Notre Dame Press, Notre Dame).

3. Allen, E. \& Seaman, J. (2006). "Entering the Mainstream: The Quality and Extent of Online Education in the United States." Sloan Foundation. http://www.sloanc.org/publications/survey/pdf/making the grade.pdf. Accessed: August 13, 2007.

4. Amin, M. and Amin, N. (2003). "Benchmarking learning outcomes of undergraduate business education." Benchmarking: An International Journal, 10 (6), pp. 538.

5. Aupperle, K. and Dunphy, K. (2003). "Benchmarking Financial Assessment in the Strategy Source: A qualitative and quantitative template." Journal of Education for Business, 78 (4), pp. 205. 
6. Aurand, T.W., DeMoranville, C., and Gordon, G.L. (Fall 2001). “Cross-Functional Business Programs: Critical Design and Development Considerations." Mid-American Journal of Business, Volume 16, pp. 2130.

7. Bain, G.S., (1992). "The future of management education”. Journal of the Operational Research Society, Vol. 4(6): pp. 557-6.

8. Barker, R.T., Gilbreath, G.H., and Stone, W.S. (1998). "The Interdisciplinary Needs of Organizations: Are New Employees Adequately Equipped?” The Journal of Management Development, Volume 17, pp. 219.

9. Bates, A. W. \& Poole, G. (2005). Effective Teaching with Technology. Jossey Bass. http://www.batesandpoole.ubc.ca/chapter-3.html. Accessed August 13, 2007

10. Becerra-Fernandez, I., Murphy, K. E., \& Simon, S. J. (2000). "Integrating ERP in the business school curriculum." Communications of the Association for Computing Machinery, 43(4), pp. 39-41.

11. Behrman, J.N. and Levin, R.J. (1984). “Are Business Schools Doing Their Job?” Harvard Business Review (January) 62 (1) pp. 140-147.

12. Bennis, Warren G. and O’Toole, James. (2005). "How Business Schools Lost Their Way." Harvard Business Review (May): Vol. 83, Issue 5, 96(9).

13. Bloom, Benjamin S. and Krathwohl. David R. (1956). Taxonomy of Educational Objectives: The Classification of Educational Goals, by a committee of college and university examiners. Handbook I: Cognitive Domain. New York, Longmans, Green.

14. Boyer, Ernest L. 1990. Scholarship Reconsidered: Priorities of the Professoriate. Princeton, NJ: The Carnegie Foundation for the Advancement of Teaching.

15. Business Week. (2005). "B-Schools for the 21 " Century.” Business Week (April 18): Issue 3929, pp. 112.

16. Carruth, Paul J. and Carruth, Ann K. (2006). "Current Trends and Future Considerations of Higher Education in Business." Journal of College Teaching \& Learning (September). Volume 3, Number 9, pp. 88 .

17. Chickering, Arthur W. and Gamson, Zelda F. (1987) "Seven principles for good practice in undergraduate education." American Association of Higher Education Bulletin. pp. 3-7.

18. Chubb, John (2004). "20 Years Later, Our Schools are Still at Risk.” Standard Daily. Storke Publications. Stanford, California, Volume 233 (January 5).

19. Closs, D. J. and Stank, T.P. (1999). "A Cross-Functional Curriculum for Supply Chain Education at Michigan State University.” Journal of Business Logistics, Volume 20, pp. 59-72.

20. Conger, J.A., \& Xin, K. (2000). "Executive Education in the $21^{\text {st }}$ Century." Journal of Management Education, 24(1), pp. 73-101.

21. Cross, Patricia K., and Steadman, M. (1996). Classroom Research: Implementing the Scholarship of Teaching. Jossey-Bass.

22. Davis, J. R. (1993). Better Teaching, more Learning: Strategies for Success in Post-Secondary Settings. American Council on Education Series on Higher Education, Oryx Press, AZ.

23. DeConinck, J., \& Steiner, T. (1999). "Developing an integrated finance and marketing course." Journal of Marketing Education, 21(1), pp. 44-50.

24. Dertouzos, M. L., Lester, R. K., \& Solow, R. M. (1989). Made in America: Regaining the competitive edge, Cambridge, Mass: MIT Press.

25. Dinmore, Ian. (1997). "Interdisciplinary and integrative learning: An imperative for adult education." Education, 117(3), pp. 452-476.

26. DeAngelo, Linda and Zimmerman Jerold L. (2005). "What's Really Wrong with U.S. Business Schools?" Social Science Research, (July).

27. Elam, E.L.R. and Spotts, H.E. (2004). "Achieving marketing curriculum integration: A live case study approach.”Journal of Marketing Education, Vol. 26, No. 1 pp.50-65.

28. Elliott, C. J., \& Goodwin, J. S. (1994), "MBA programs and business needs: is there a mismatch?” Business Horizons, 37(4), pp. 56-60.

29. Etzioni, A. (2002). "When is comes to ethics, B-schools get an F". Washington Post, (August 4). B04.

30. Fleming, Debra L. (2004). "Measuring Up: The Future Challenges of Higher Education," presentation at Long Island's Business Men's Association (LIMBA), Oakdale, New York, September 17.

31. Gardner, Howard. (1993). Frames of Mind: The Theory of Multiple Intelligences. $10^{\text {th }}$ Edition. New York: Basic Books Publishing. 
32. Gardner, H. (2000). “Can technology exploit our many ways of knowing?” In D.T. Gordon (Ed.). The digital classroom: How technology is changing the way we teach and learn. Harvard Education, Cambridge, MA.

33. Gerdes, Lindsey, (2005). "B-Schools with a Niche.” Business Week, Sept. 5, pp. 70-72.

34. George, M. A., \& Davis, Wily, P. (2000). "Team teaching a graduate course.” College Teaching, 48(2), 7580.

35. George, Richard J. (1987). "Teaching Business Ethics: Is There a Gap between Rhetoric and Reality?" Journal of Business Ethics, 6, pp. 513-518.

36. Glaser, R. (1990). The reemergence of learning theory within instructional research, American Psychologist (January): pp. 29-39.

37. Goodswell A., Maher, M., and Tinto, V. (1992). Collaborative Learning: A Source Book for Higher Education. University Park, PA: National Center for Post secondary Teaching, Learning, and Assessment at Pennsylvania State University.

38. Hancock, T. (1998). "The new MBA: flies in the paradigm," Business Horizons, 42(4), pp. 41-44.

39. Heskett, Jim. (2005). "How Can Business Schools Be Made More Relevant?” Harvard Business School's Working Knowledge Series, (July), Issue 5.

40. Hirsh, W., Burgoyne, J., and Williams, S. (2002). The Value of Business and Management Education. Report for the Association of Business Schools.

41. Katz, Adolph I. (1990). "The Status of Business Ethics Education in Business School Curricula." Information \& Management, 18. pp. 123-130.

42. Kennedy, E.J., Lawton, L. and Walker, E. (2001). "The case for using live cases: Shifting the paradigm in marketing Education.” Journal of Marketing Education, Vol. 23, No. 2, pp.145-151.

43. Lave, J. (1988). Cognition in Practice. Cambridge, England: Cambridge University Press.

44. Malekzadeh, R. Ali. (1998). "Diversity, Integration, globalization, and critical thinking in the upper division." Journal of Management Education, 22(5), pp. 590-603.

45. McKenna, J.F., Cotton, C.C. \& Van Auken, S. (1995). "Business School Emphasis on Teaching, Research, and Service to Industry: Does Where You Sit Determine Where You Stand?" Journal of Organizational Change Managemen, Vol. 8(2), pp. 3- 16.

46. McNamara, Daniel E. (2006). "The Relevance Of Business School Education, What Do You Think?" Journal of College Teaching \& Learning, (November), Volume 3, Number 11.

47. Michaelsen, L. K. (1999). "Integrating the core business curriculum; an experienced-based solution." Graduate Management Admissions Council, 15(2), pp. 9-17.

48. Mintzberg, H. (2004). Managers Not MBAs: A Hard Look at the Soft Practice of Managing and Management Development. Berrett-Koehler, San Francisco, CA.

49. Navarro, Peter. (2004). "Why Johnny Can’t Lead.” Harvard Business Review (December), Vol. 82, Issue 12, 17.

50. Pfeifer, J. and Sutton, R. I. (2000). The knowing-doing gap. Boston: Harvard Business School Press.

51. Pfeffer, J. and Fong, C. (2002). "The End of Business Schools? Less Success than Meets the Eye."

52. $\quad$ Academy of Management Learning and Education Journal, Sept. 2002.

53. Pfeffer, J. and Fong, C.T. (2004). "The Business School Business: Some Lessons from the US Experience." Journal of Management Studies, (December), pp. 1501-1520.

54. Phelps, Raymond A., Aggarwal, Ajay K. and Taylor, Patrick A. (2006). "Looking for Niches in All the Right Places: Designing An MBA Program For The Next Decade." Journal of College Teaching \& Learning, (September), Volume 3, Number 9.

55. Phleps, Raymond A. and Kimball, Marshall P. (1994). "A Business School Portfolio of MBA Majors for the Next Decade: The Implications of Employment Trends through the Year 2005,” Presentation at Jackson State University, 1994.

56. Porter, L. and McKibben, L. E.. (1988). Management Education and Development: Drift or Thrust into the 21st Century. New York: McGraw-Hill Book Company.

57. Puto, Christoper P. (2005). "Is this degree still worth mastering?" In a column in the May 22, 2005 Minneapolis Star- Tribune.

58. Razzouk, N.Y., Seitz, V. and Rizkallah, E. (2003). "Learning by doing: Using experiential projects in the undergraduate marketing strategy course." Marketing Education Review, Vol. 13, No. 2. 
59. $\quad$ Resnick, L.B. (1987) "Learning in School and Out." Educational Researcher, Vol.16, No.9, pp. 13-20.

60. Scherer, M. (1999). "The understanding pathway: A conversation with Howard Gardner." Educational Leadership, Vol. 57, No 3, pp.12-16.

61. Slater, Jill Smith, McCubbrey, Donald J. and Scudder. Richard A. (1995). "Inside an integrated MBA: An information system view." MIS Quarterly, 19(3), pp. 391-410.

62. Stephens, C. and O'Hara, M. (2001). "Benchmarking the required information systems course in AACSB accredited MBA programs: An analysis of course content and process." The Journal of Computer Information Systems, 41 (4), pp. 38.

63. Stern, Stefan. (2004). "MBAs with a Heart. Management.” Today (October), 4 (2).

64. Tabor, S.W. (2005). "Achieving significant learning in E-Commerce education through small business consulting projects.” Journal of Information Systems Education, Vol. 16(1).

65. The American Institute of Certified Public Accountants, AICPA (2006). AICPA report on The Supply of Accounting Graduates and the Demand for Public Accounting Recruits.

66. The Association to Advance Collegiate Schools of Business International. AACSB International. (1996). Management Education and Development: Drift or Thrust into the 21st Century.

67. The Association to Advance Collegiate Schools of Business International. AACSB International (2002). Task Force on Management Education. Management Education at Risk.

68. U.S. Department of Education's National Commission on Excellence in Education (1983). A Nation at Risk.

69. U.S. Department of Labor and the Secretary's Commission on Achieving Necessary Skills (1991). SCANS issued the report What Work Requires of Schools, and its companion report, A Blueprint for Action: Building Community Coalitions.

70. U.S. Department of Labor, The Secretary’s Commission on Achieving Necessary Skills (2002). Learning a Living: A Blueprint for High Performance. A SCANS Report for America 2000.

71. U.S. Department of Labor, Bureau of Labor Statistics, Occupational Employment Projections Handbook, 2004 to 2014 Edition.

72. U.S. Department of Labor, Bureau of Labor Statistics, Occupational Outlook Handbook, 2004-2014 Edition.

73. Whetten, A. and Clark, Sue C. (1996). "An integrated model for teaching management skills.” Journal of Management Education, 20(2), pp. 152-181.

74. Young, M.R. (2002). "Experiential Learning = Hands - On + Mind - On.” Marketing Education Review, Vol. 12, No. 1.

75. Young, Terry W. and Hall, Owen P. (2007). "Management Education Benchmarking Designing Customized and Flexible MBA Programs.” Journal of College Teaching \& Learning, (March), Volume 4, No. 3.

76. Zych, J.M. (1997). “Adding case materials to reinforce the realism in marketing simulations.” Marketing Education Review, Vol. 7, No. 2. 
NOTES 